you don't." I would like to recommend an article by B.G. Braun (1984). Professor Merskey seems to overestimate the power of hypnosis. As Braun explains, MPD cannot be produced by hypnosis, but it can be unveiled by hypnotic techniques.

BraUN, B. G. (1984) Hypnosis creates multiple personality: myth or reality? International Journal of Clinical and Experimental Hypnosis, 32, 191-197.

Studiegången 17-306

S-41681 Gothenburg

Sweden

Ulla KaRILAMPI

\section{The neglect of anger in Western psychiatry}

SIR: I read with interest the review on anger by Kennedy (Journal, August 1992, 161, 145-153), and fully support the view that the clinical assessment of anger, its antecedents, consequences, and treatability has been neglected. In the handbook on psychiatric examination (Institute of Psychiatry, 1987) which is piously used by psychiatric trainees, mood assessment includes, among others, spirits, anxiety, tearfulness, and guilt, but not anger. Clinically, extreme states of depression or anxiety are readily regarded as a disorder which is out of a patient's own control and requires psychiatric treatment. In contrast, similarly severe attacks of rage are often conceived, if not stigmatised, as being within a person's own moral responsibility, unless the anger is epiphenomenally thought to underlie manifest depression and hence should be 'ventilated'. Unlike sadness or apprehension, anger easily provokes negative countertransference and may selectively be repressed by the psychiatric profession. If morbid anger has a biological basis akin to depression or anxiety and responds equally well (or poorly!) to psychiatric treatment, then many affected subjects may have been unjustifiably sent to prison.

Dr Kennedy may like to add to his review the Chinese concepts of emotions and pathogenesis $(\mathrm{Wu}$, 1982). Traditional Chinese medicine, as recorded in the classical text of Huang-ti Nei-ching (the 'Bible of Chinese medicine') more than 2000 years ago, stresses the importance of a balanced life, and the regulation of the seven emotions ( $q$ i-qing). Instead of a simplistic depression-elation paradigm, the seven emotions include joy, anger, worry, contemplation, sorrow, apprehension, and fright which may dialectically interact with one another. Depression does not rank high among these emotions, explaining to some extent the reputed lack of lexicon to express depression and the controversial issue of there being less depression in the Chinese (Xu, 1987). Excessive emotional activity of any kind may cause imbalance of $Y$ in and Yang, blockade of $Q i$, malfunction of organs and hence illness. More specifically, violent anger is hurtful to Yin, and violent joy is hurtful to Yang. A person with an irascible personality is described as hou-qu-ta rather than 'borderline' among Mandarin-speaking Chinese (Lin et al, 1980). Sorrow counteracts anger, lending some credence to the psychoanalytic theory that anger repressed and turned against the self becomes depression.

In investigating the Korean culture-bound 'anger' syndrome of Hwa-Byung, Lin et al (1992) recently suggest the addition of an 'anger syndrome' in the DSM-III system. Notwithstanding the social risk of legitimising anger and aggression as disease states, morbid anger deserves a fair share of the enormous and not always fruitful research efforts that Western psychiatry has elected to spend on depressive and anxiety states.

Institute of Psychiatry (1987) Psychiatric Examination: Note on Eliciting and Recording Clinical Information in Psychiatric Patients (2nd edn). Oxford: Oxford University Press.

LIN, K. M., KLeinman, A. \& LIN, T. Y. (1980) Overview of mental disorders in Chinese cultures: review of epidemiological and clinical studies. In Normal and Abnormal Behaviour in Chinese Culture (eds A. Kleinman \& T. Y. Lin), pp. 237-272. Boston: D. Reidel.

—, LAU, J. K. C., Yамамoto, J., et al (1992) Hwa-Byung-a community study of Korean Americans. Journal of Nervous and Mental Disease, 180, 386-391.

Wu, D. Y. H. (1982) Psychotherapy and emotion in traditional Chinese medicine. In Cultural Concepts of Mental Health and Therapy (eds A.J. Marsella \& G.M. White), pp. 285-301. Dordrecht: Reidel.

XU, J. M. (1987) Some issues in the diagnosis of depression in China. Canadian Journal of Psychiatry, 32, 368-370.

SiNG LeE

Department of Psychiatry

Chinese University of Hong Kong, Shatin

Hong Kong

\section{The Northfield Experiments}

SIR: As psychoanalysts practising analytic group psychotherapy in a mental hospital, we read with great interest Harrison \& Clarke's paper about the Northfield Experiments (Journal, May 1992, 160, 698-708). It might be of interest to the readers of the Journal to know that there is a psychotherapeutic ward in a state hospital in Switzerland (Haus 14, Kantonale Psychiatrische Klinik Wil, St Gallen) which is explicitly committed to the concepts developed at Northfield. This is the only psychoanalytically orientated unit in a large clinic, and we 
encounter many of the problems described by Drs Harrison \& Clarke. In dealing with them we find the ideas of Tom F. Main, and his emphasis on the careful consideration of the community as a whole, especially helpful. We share with Wilfried R. Bion the experience that, given the proper setting, even very disturbed patients can develop a sense of responsibility to their group, to the hospital, and to society as a whole.

As we have to defend our general analytic approach continuously against many odds, we are grateful to Drs Harrison \& Clarke for their summary of the historical roots of the work we do. We certainly agree that the "lessons learned at Northfield remain relevant to the practice of psychiatry today".

HEDI HAFFNER

Institut für Psychoanalyse

Waffenplatzstrasse 36

Postfach 6906

CH-8023 Zürich

Switzerland

\section{Self-neglect in adult life}

SIR: I read with interest the recent case reports on self-neglect in adult life (Journal, August 1992, 161, 265-267). These two cases are not the only cases of squalor among younger patients. MacMillan \& Shaw (1966) noted this in their original series, and this issue has been debated more recently (Shah, 1991). It has been suggested that age is not important in the development of this syndrome (Shah, 1991). Frontal lobe dysfunction (with or without dementia) has been suggested to be associated with the syndrome (Orrell et al, 1989: Shah, 1992). It would be interesting to know if Drs Vostanis \& Dean have any evidence of frontal lobe dysfunction in either patient (particularly Case 1, who had the revised Weschler Adult Intelligence Scale test).

These patients can be managed through psychiatric services and the Mental Health Act when there is evidence of mental illness (Cybulska \& Rucinski, 1986; Mulroy \& Shah, 1992). However, up to $50 \%$ of these patients do not have psychiatric disorder (MacMillan \& Shaw, 1966; Clark et al, 1975). In such situations, Section 47 of the National Assistance Act 1948 could be used. Here the patient can be removed to a place of safety (usually a hospital bed) "if he is suffering from grave chronic disease or, being aged, infirm or physically incapacitated, is living in insanitary conditions and is unable to devote to himself and is not receiving from other persons proper care and attention". This act offers powers of placement but no powers of treatment. The local environmental health department can use other legislation to deal with squalor (Mulroy \& Shah, 1992). Section 83 of the Public Health Act 1936 (amended by Section 35 of the 1961 Act) suggests that if "filthy or verminous premises" exist, then notice can be served to the owners or occupiers of the property to clean up. If this is not complied with then the environmental health department can clean up. An adjunct to this is Section 84 of the Public Health Act 1936, whereupon "filthy and verminous persons" can be "deloused".

Prevention of damage by the Pest Act 1949 (Section 4) may be useful if there is evidence of infestation with rats and mice. This can be served upon owners and occupiers. The neighbours may be able to invoke the nuisance provision under Section 80 of the Environmental Protection Act 1990.

\footnotetext{
Clark, A., Manikar, G. \& Gray, I. (1975) Diogenes syndrome: a clinical study of gross neglect in old age. Lancet, $i, 366-368$.

Cybulska, E. \& Rucinski, J. (1986) Gross self neglect in old age. British Journal of Hospital Medicine, July, 21-24.

MACMillan, D. \& SHAW, P. (1966) Senile breakdown in standards of personal and environmental cleanliness. British Medical Journal, ii, 1032-1037.

Mulroy, R. \& SнAн, A. K. (1992) Indescribable squalor. Update, (in press).

Orrell, M., Sahakian, B. \& Bergmann, K. (1989) Self neglect and frontal lobe dysfunction. British Journal of Psychiatry, 155, 101-105.

Sнан, A.K. (1991) Senile squalor syndrome - a misnomer? Care of the Elderly, 3, 52.

(1992) Senile squalor syndrome: a small series. Care of the Elderly, 4, 299-300.
}

Academic Unit for Psychiatry of Old Age

Ajit Shah

St Vincent's Hospital Clinical School

Mont Park Hospital Campus

Private Bag No. 1

Rosanna

Victoria 3084

Australia

\section{The designation of black people in psychiatric} research

SIR: Anthropologically speaking, there are only three major ethnic divisions of Homo sapiens, namely the negroid, caucasoid and mongoloid races. Although the words 'negroid' and 'negro' are still used in anthropology, there has been a tendency to avoid their use elsewhere, as these terms have, principally thanks to American racism and the resultant civil rights movements, acquired a connotation of racial abuse. (Similar considerations apply to the term 